"Factors may drive the commercial banks lending: evidence from Jordan"

\begin{tabular}{|c|c|}
\hline AUTHORS & Ayman Mansour Khalaf Alkhazaleh \\
\hline ARTICLE INFO & $\begin{array}{l}\text { Ayman Mansour Khalaf Alkhazaleh (2017). Factors may drive the commercial } \\
\text { banks lending: evidence from Jordan. Banks and Bank Systems, 12(2), 31-38. } \\
\text { doi:10.21511/bbs.12(2).2017.03 }\end{array}$ \\
\hline DOI & http://dx.doi.org/10.21511/bbs.12(2).2017.03 \\
\hline RELEASED ON & Friday, 23 June 2017 \\
\hline RECEIVED ON & Wednesday, 08 March 2017 \\
\hline \multirow[t]{2}{*}{ ACCEPTED ON } & Tuesday, 25 April 2017 \\
\hline & $(\mathrm{cc}) \mathrm{EY}$ \\
\hline LICENSE & $\begin{array}{l}\text { This work is licensed under a Creative Commons Attribution } 4.0 \text { International } \\
\text { License }\end{array}$ \\
\hline JOURNAL & "Banks and Bank Systems" \\
\hline ISSN PRINT & $1816-7403$ \\
\hline ISSN ONLINE & $1991-7074$ \\
\hline PUBLISHER & LLC "Consulting Publishing Company "Business Perspectives" \\
\hline FOUNDER & LLC "Consulting Publishing Company "Business Perspectives" \\
\hline & ニニニ \\
\hline NUMBER OF REFERENCES & NUMBER OF FIGURES \\
\hline 23 & 2 \\
\hline
\end{tabular}

(C) The author(s) 2022. This publication is an open access article. 


\title{
Factors may drive the commercial banks lending: evidence from Jordan
}

\begin{abstract}
In an attempt to shed more light on the behavior of lending in banks, especially in the environment of developing countries, this study aims at explaining the impact of some factors proposed as determinants of bank lending in Jordanian commercial banks by benefiting from the financial reports of thirteen banks during the period 2010-2016. The study, in order to achieve the objectives and to test the main hypotheses has adopted Ordinary least square model (OLS). The most important results of the study are a statistically significant adverse effect of both credit risk and liquidity on bank lending, while there is a significant positive effect of the return on assets, size of the bank measured by assets, inflation, money supply and growth in gross domestic product in determining the level of lending. In addition, the study does not show a significant statistical effect between investments, the volume of deposits and bank lending in the same time frame. The review points out that because of the negative impact of liquidity and credit risk factors, commercial banks need to focus more on reducing their impact because presence of this impact at the end will decrease the ability of these banks to provide loans and stay in the banking market.
\end{abstract}

Keywords: lending, liquidity, credit risk, deposit, inflation, GDP.

JEL Classification: G21, G29, C33, E23, E51.

Received on: $8^{\text {th }}$ of March, 2017.

Accepted on: $25^{\text {th }}$ of April, 2017.

\section{Introduction}

There is no doubt that banks are considered in most of the literature to be the most important institutions that have a great impact on the economy of any country no matter of small or large size, and Banga (2013) pointed out banks to be considered the spirit of economy. The importance of bank lending and the provision of credit facilities is in the fact that the more banks that perform better, the more different sectors of the economy can benefit more and, thus, achieve an adequate growth rate. In view of this, Akinlo and Oni (2015) stated that the issue of determining factors, which may affect the level of lending, is still a subject of research and is not resolved greatly, where there are still differences in the identification of which factors that have a strong impact and are less impacted with the absence of agreements between many studies on the direction of those impacts, if any.

The bank credit is deliberated as one of the vital functions executed by banks, where it adds to the arrangement of the essential financing for all the sectors in the country, comprising the sectors of the household, business and government. The credit granted to those sectors is considered to be important for exercising their tasks in business, operations and investments, which helps

(C) Ayman Mansour Khalaf Alkhazaleh, 2017.

Ayman Mansour Khalaf Alkhazaleh, Assistant Professor, Middle East University, Amman, Jordan.

This is an Open Access article, distributed under the terms of the Creative Commons Attribution 4.0 International license, which permits unrestricted re-use, distribution, and reproduction in any medium, provided the original work is properly cited. them to achieve a real growth in output, which will reflect positively on the economy as a whole (Rababah, 2015).

The main work of the banks in general is to provide loans to the various public and private sectors in order to exploit all the money resources available, such as deposits in the achievement of profits that ultimately maximize the value of the bank, where bank loan is characteristiccally the major asset and the prime source of revenue for banks as pointed out by Malede (2014). Banks in Jordan, like the rest of the banks in different economies, lead the main work of receiving deposits and providing loans to different sectors, thus contributing to maximizing the economic growth of the country. This is in full accordance with the study of Acharya et al. (2009) which mentions that many reviews have indicated the fact that increasing the loans granted by such banks helps to boost the growth of economy.

With respect to the Jordanian economy, signs mention that it is based on banks, where the credit facilities allowed by the banks in Jordan signified $80.5 \%$ of the GDP during the period 2000 to 2013 (Rababah, 2015). Through the earlier pointer, plainly banks have a noteworthy influence in financing the Jordanian economy. The credit facilities allowed by the banks in Jordan increased around 1.5 times from 2010 to 2015 expanded from around 14.5 billion dinars in 2010 to achieve JD 21.10 billion toward the finish of 2015 (Alabedallat, 2017). This solid development in the credit facilities reveals large economic development rates accomplished by the Jordanian economy in that period. Table 1 demonstrates the 
advancement of the credit facilities conceded by the banks working in Jordan amid the period 2000-2015.

Banks for the most part convert liquid resources such as deposits into illiquid resources like advances and loans. This bank's activity is affected by a group of elements that is macroeconomic and industry level features. In view of the above, the principle objective of this review was to examine the main determinants of Jordanian commercial banks lending behavior using the period 2000-2016. More specifically, the study was designed to address the following particular objectives:

- To determine the impact of internal factors (return on assets, bank size, credit risk, liquidity ratio, volume of deposits and investment) on commercial bank lending.

- To determine the impact of external factors (inflation rate, GDP and money supply) on commercial banks lending.
Table 1. Credit facilities conceded by the Jordanian banks

\begin{tabular}{|c|c|c|}
\hline Credit facilities & $\begin{array}{c}\text { GDP } \\
\text { at current market prices }\end{array}$ & Year \\
\hline 4546.5 & 5998.6 & 2000 \\
\hline 4948.9 & 6363.7 & 2001 \\
\hline 5130.0 & 6794.0 & 2002 \\
\hline 5262.400 & 7228.8 & 2003 \\
\hline 6189.200 & 8090.7 & 2004 \\
\hline 7744.300 & 8925.4 & 2005 \\
\hline 9761.900 & 10675.4 & 2006 \\
\hline 11295.600 & 12131.4 & 2007 \\
\hline 13044.300 & 15593.4 & 2008 \\
\hline 13317.200 & 16912.2 & 2009 \\
\hline 14451.400 & 18762.0 & 2010 \\
\hline 15851.200 & 20476.6 & 2011 \\
\hline 17829.800 & 21965.5 & 2012 \\
\hline 18939.700 & 23851.6 & 2013 \\
\hline 19274.500 & 25437.1 & 2014 \\
\hline 21103.500 & 26637.4 & 2015 \\
\hline
\end{tabular}

Source: Al-abedallat (2017).

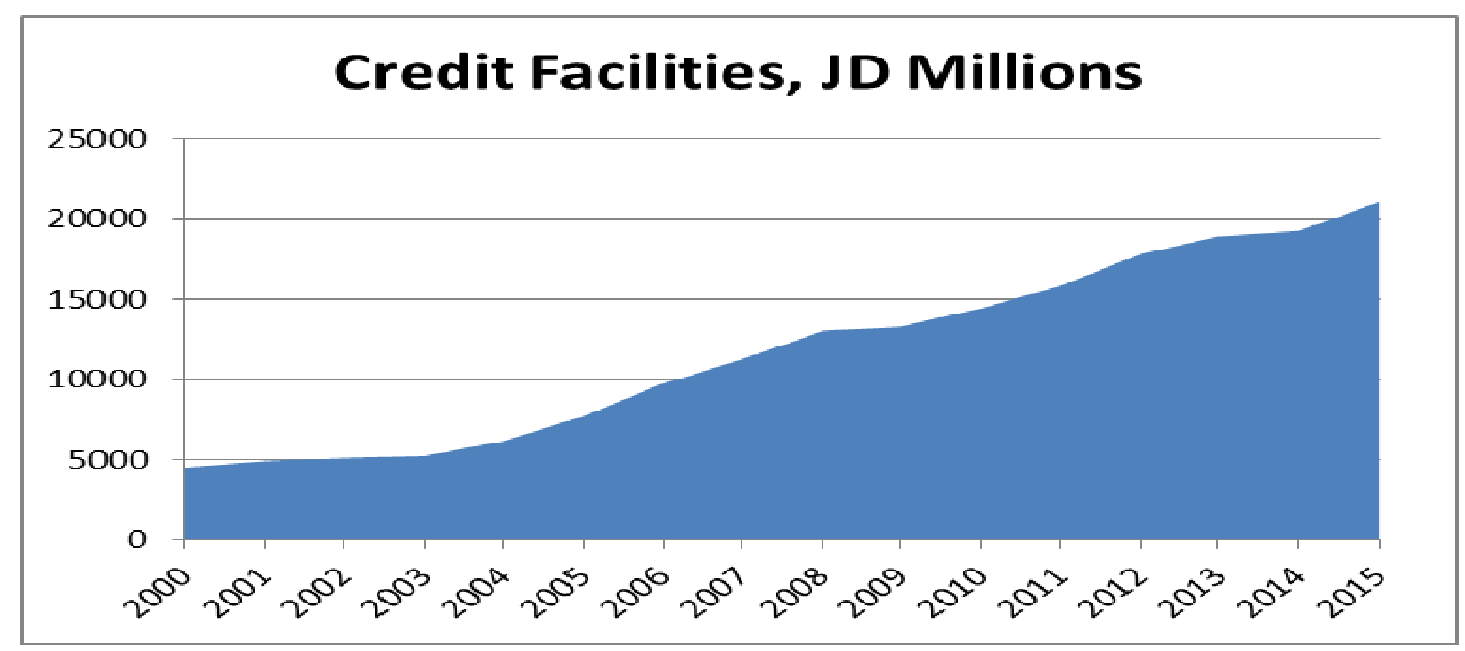

Fig. 1. The credit facilities delivered by the banks functioning in Jordan

\section{Literature review}

Literature proposes potential determinants of bank lending conduct, which may be categorized into internal and external factors. There are a number of previous studies that have inspected these factors, where the preliminary point may be the study, conducted by Melitz and Parduein (1973), who recognized equation of supply and demand for loans utilizing regression investigation on quarterly data for the period 1951-1969. The authors determined that there was a positive relative between the weighted assets, the interest rate of short-term business loans, the interest rate of deposits and contribution loans. On the contrary, there was recorded an adverse relation between the rate of threeyear and five-year government bonds and amount of loans. In addition Laffont and Garcia (1977) assessed model of supply and demand for commercial loans in the Canadian aspect for the period 1965 to 1975. The authors established that these variables were significant and the supply of credit has a direct impact of basic interest rate from loans, term deposits, deposits at sight and the index of industrial production. On the other hand, there was recorded an adverse impact between the supply of credit and the difference between the interest rate of government bonds, interest rate of longterm loans, the difference between the deposit rate and the basic rate of interest on loans.

Recently, a number of studies have attempted to study the determinants of bank lending. For example, the aim of Awdeh (2016) was to review the determinants of the development of credit in the Lebanese state through the use of financial data covering sixteen years from 2000 to 2015 for thirty four commercial banks. The results showed that factors contributed to the enhancement of bank credit to the private sector such as GDP growth, inflation, deposit growth, and money supply, while the study showed that the lending interest rate, credit risk, T-bill rate, public borrowing, and 
remittance inflows have a negative impact on loan growth. The study also explored the impact of one year lag of all exploited variables to examine if they have a delayed influence on credit, where it is found for instance, ROA does not affect credit growth, whereas its lag lowers credit growth; lag LLP recorded the contrary effect of LLP; the impact of a change in money supply increases considerably after one year; and in conclusion, the negative impact of remittances diminishes after one year. On the other hand, Moussa and Chedia (2016) used financial data over the period from 2000 to 2013 concerning a sample of 18 Tunisian banks to identify the impact of some internal and external factors on bank credit. The study concluded that among external factors, only inflation has a significant impact on loans, while return on assets, net interest margin, and liquidity as internal factors have had a significant impact on the volume of bank loans. Furthermore, guided by the theory of money supply, Ayieyo (2016) identified the effect of deposit size and interest rate on total loans from nine commercial banks in Kenya over a ten-year period from 2002 to 2011. Using the multiple regression analysis, the results indicated that interest rates were negatively correlated and significantly affected the total loans provided. In addition, the volume of deposits has a significant and direct impact on the total loans provided. The study recommended that commercial banks should set up ways to increase their profits through fee and commission income as interest rate yields go down as lending rates increase. In Nigerian context, Akinlo and Oni (2015) utilized the error correction modeling technique to investigate the leading factors influencing bank credit presented to the private sector over the period 19802010. The consequences show credit was likely increased by the effect of broad money, cyclical risk premium and liquidity ratio. On the contrary, prime lending rate and reserve ratio cause a reduction in credit. Moreover, private credit rises with inflation, but not one to one, sense that inflation tends to reduce real bank credit.

By using Ordinary Least Square (OLS), Malede (2014) conducted a study using financial data for eight Ethiopian commercial banks over a period of seven years from 2005 to 2011. This study showed evidence of the effect of size, credit risk, GDP ratio and liquidity on lending in commercial banks, while it did not show any evidence of the effect of deposits, investment, cash reserve required and interest rates. Hanh (2014) also used financial data for 146 different countries at the level of economic growth and for twenty-four years in the period 1990-2013 in an attempt to study the determinants of bank credit. This study found that the country's economic growth affects bank credit. The study also found that the strength of the banking system has had an impact on the bank's progress. By contrast, dependence on foreign capital inputs makes its banking sector more vulnerable to external turmoil. In addition, in an attempt to identify the factors that could affect bank lending. Moreover (Amidu, 2014), through bank statements, of 264 banks spread across 24 subSaharan African countries showed that regulation of the banking market affects the provision of credit in an environment in which the financial sector is improved and banks are allowed to operate freely. In contrast, there was a sign of a relationship between bank credit and financial strength of banks.

Ladime, Sarpong-Kumankomah and Osei (2013) conducted a study on the determinants of bank lending behavior in Ghana. Where they found that the behavior of bank lending is directly and positively affected by the size of the bank and the structure of bank capital and also found evidence of the negative impact of the central bank lending rate and exchange rate. And in the Turkish context, Tomak (2013) used quarterly data for fifteen commercial banks and three state banks from 2003 to 2012 to find that the performance of the commercial loans depends on size, total liabilities, and bad loans on total loans, as well as inflation rate.

Sharma and Gounder (2012) inspected the bank credit delivered to the private sector in seven countries in the South Pacific during the period 1982-2009. The results showed that the average interest rates and the rate of inflation may have a negative impact on the rate of growth in loans, while strong economic growth, the volume of deposits and assets had a positive impact on credit growth. Moreover study for Colombia (Moreno et al., 2012) indicated that interbank rate, national debt to GDP, household consumption to GDP and the level of investment to GDP were the key determinants of credit portfolio.

In the same area of interest, Chernykh and Theodossiou (2011) led research on Russian banks. The study showed that the bank's ability to provide more long term loans is affected by the capital, the size and availability of long term liabilities. It also found that banks are reluctant to grant loans with a repayment period of more than 3 years. In addition, the study stated that banks with a low level of capital provide shorter term loans, and that banks operating in highly competitive regions are reluctant to grant long term loans. The study also indicated that the bank's owners had no impact on loan volume.

Stavárek and Vodová (2010) used quarterly data from 1994 to 2007 to study the determinants that affect the total volume of loans provided to residents and nonresidents in the Czech Republic. The authors demonstrated the positive impact of lending capacity (deposits, funds obtained from the interbank market or issue debt securities) and interest margins on lending volume. In addition and as against general expectations, the study found that return on average assets ratio was a negative impact on the volume of loans but there was a positive effect of return on equity. 
With regard to the situation in the Jordanian market, Rababah (2015) reviewed the banking lending factors in Jordan during 2005-2013 by using the ratio of credit facilities to total assets as a response variable. The study showed that the ratio of non-performing loans, liquidity ratio and window rate have a negative impact on credit facilities. However, the study showed that the size of the bank and economic growth have a direct and significant impact on the ratio of loans as well. In the same field, Alkilani and Kadummi (2015) indicated that the behavior of lending is heavily influenced by internal factors such as net profit after tax and is influenced by external factors such as GDP. The study also pointed out that the volume of loans provided by Jordanian banks is not affected by the interest rate. Finally, the study recommended that the determinants of lending are not all agreed, further analysis is needed to achieve further agreement between studies. Earlier studies related to this matter have recognized various factors believed to be influential of lending conduct of developed and developing economies. Foregoing studies had explored the determining factors of commercial banks lending to display the effect of internal and external variables on banks' lending. Nevertheless, though there are some reviews on the determinants of lending behavior, but there was no full agreement among themselves on the number and type, and the consequence of different factors in their aptitude to interpret the behavior of lending among both developed and developing economies. Fundamentally, this work is motivated by the previous mentioned reason and shortage of empirical work on determinants of credit in developing economies such as Jordan. Ultimately, the outcomes will deliver insights into how the situation in Jordan compared with that of advanced and industrialized economies. Accordingly, the researcher comes in a position to inspect this notion in Jordan case by using seven years panel data from 13 commercial banks from 2010 up to 2016.

\section{Hypotheses of the study}

In order to achieve the objectives of the study and to answer clearly on the problem statement, hypotheses have been constructed in a way that can be tested to arrive at reliable scientific results and generalize them. The following hypotheses have been adopted:

- $\mathrm{H}_{1}$ : There is significant impact of return on assets on lending in Jordanian commercial banks.

- $\mathrm{H}_{2}$ : There is significant impact of bank size on lending in Jordanian commercial banks.

- $\mathrm{H}_{3}$ : There is significant impact of credit risk on lending in Jordanian commercial banks.

- $\mathrm{H}_{4}$ : There is significant impact of liquidity ratio on lending in Jordanian commercial banks.

- $\mathrm{H}_{5}$ : There is significant impact of deposits on lending in Jordanian commercial banks.
- $\mathrm{H}_{6}$ : There is significant impact of investment on lending in Jordanian commercial banks.

- $\mathrm{H}_{7}$ : There is significant impact of inflation rate on lending in Jordanian commercial banks.

- $\mathrm{H}_{8}$ : There is significant impact of GDP on bank lending in Jordanian commercial banks.

- $\mathrm{H}_{9}$ : There is significant impact of money supply on lending in Jordanian commercial banks.

\section{Research methodology}

3.1. Sample data. To achieve the objectives of this study, a panel of seven years financial data of sampled banks have been utilized to cover the years from 2010-2016. Banks chosen are those banks whose published financial reports and required data were available for the whole period under review. However, the number of local banks operating in Jordanian territory is counted sixteen as shown in table 2. The central bank classifies local banks into three Islamic banks and thirteen commercial banks. All local commercial banks have been accredited for the purpose of this work in line with the proposals for defining the appropriate sample size for making generalization. The analyses were carried out in stages. First, variance inflation factor was employed to test the problem of muticollinearity and BreuschPagan / Cook-Weisberg test was used to check for heteroskedasticity. Secondly, data collected were analyzed using the Ordinary Least Square (OLS) to ascertain the effect of internal and external factors on lending of commercial banks in Jordan.

Table 2. List of banks in study population

\begin{tabular}{|c|c|c|c|}
\hline $\begin{array}{l}\text { Type of } \\
\text { bank }\end{array}$ & $\begin{array}{c}\text { Number } \\
\text { of bank }\end{array}$ & Bank's name & $\begin{array}{l}\text { Establishment } \\
\text { date }\end{array}$ \\
\hline \multirow{13}{*}{$\begin{array}{c}\text { Commercial } \\
\text { banks }\end{array}$} & 1 & Arab Bank UDP & 1930 \\
\hline & 2 & Arab Banking Corporation & 1989 \\
\hline & 3 & Bank of Jordan & 1960 \\
\hline & 4 & Cairo Amman Bank & 1960 \\
\hline & 5 & $\begin{array}{l}\text { Capital Bank formerly Export } \\
\text { \& Finance Bank }\end{array}$ & 1996 \\
\hline & 6 & $\begin{array}{l}\text { Jordan Commercial Bank formerly } \\
\text { Jordan Gulf }\end{array}$ & 1978 \\
\hline & 7 & Jordan Kuwait Bank & 1977 \\
\hline & 8 & $\begin{array}{l}\text { Jordan Ahli Bank formerly Jordan } \\
\text { National Bank }\end{array}$ & 1956 \\
\hline & 9 & $\begin{array}{l}\text { The Housing Bank for Trade } \\
\text { and Finance }\end{array}$ & 1974 \\
\hline & 10 & Arab Jordan Investment Bank & 1978 \\
\hline & 11 & Jordan Investment and Finance Bank & 1989 \\
\hline & 12 & $\begin{array}{l}\text { SocieteGenerale Bank / Jordan } \\
\text { formerly Middle East Investment Bank }\end{array}$ & 1993 \\
\hline & 13 & $\begin{array}{l}\text { Union Bank for Saving and Invest- } \\
\text { ment }\end{array}$ & 1991 \\
\hline \multirow{3}{*}{ Islamic bank } & 14 & Islamic International Arab Bank & 1997 \\
\hline & 15 & $\begin{array}{l}\text { Jordan Islamic Bank for Finance } \\
\text { Investment }\end{array}$ & 1979 \\
\hline & 16 & Dubai Islamic Bank Jordan & 2010 \\
\hline
\end{tabular}

Source: Central Bank of Jordan. 
3.2. Study variables and conceptual framework. The variables that were highlighted during the study were divided into dependent variable and independent variable, dependent variable which is governed by many factors was calculated (lending) from the financial ratios of credit facilities to the total assets. As for the independent variables, data have been collected on these variables from bank. This subdivision presents the proxies that were engaged to operationalize the variables. Plus those factors were selected by taking into consideration the availability of data and its influence on lending behavior in banks as mentioned in literature. Independent factors have been carefully selected as potential determinants of lending as stated in previous theoretical literature and based on previous studies in the banking sectors of different countries of the world. The availability of financial information about these determinants has also been taken into consideration as well.
Table 3. Definition of variables (proxies), symbols and expected signs

\begin{tabular}{|l|l|l|c|}
\hline Symbol & \multicolumn{1}{|c|}{ Variables } & \multicolumn{1}{|c|}{$\begin{array}{c}\text { Description and measurement of } \\
\text { variables }\end{array}$} & $\begin{array}{c}\text { Expected } \\
\text { sign }\end{array}$ \\
\hline LND & Lending & Credit facilities / Total assets & \\
\hline ROA & Return on assets & Net income / Total assets & + \\
\hline BZ & Bank size & Natural logarithm of total assets. & + \\
\hline CR & Credit risk & $\begin{array}{l}\text { The ratio of non-performing loans to } \\
\text { total loans for bank i at time t }\end{array}$ & + \\
\hline LR & Liquidity ratio & Liquid asset / Total assets & + -- \\
\hline DEP & Volume of deposit & Total deposits / Total assets & + \\
\hline IP & $\begin{array}{l}\text { Investment } \\
\text { portfolio }\end{array}$ & $\begin{array}{l}\text { A bank's financial instruments in } \\
\text { stocks and bonds }\end{array}$ & - \\
\hline INF & Inflation rate & $\begin{array}{l}\text { The annual change in the consumer } \\
\text { price index. }\end{array}$ & + \\
\hline GDP & $\begin{array}{l}\text { Gross domestic } \\
\text { Product }\end{array}$ & $\begin{array}{l}\text { Current year real GDP minus } \\
\text { Previous year real GDP / } \\
\text { previous year real GDP }\end{array}$ & + \\
\hline M2 & Money supply & $\begin{array}{l}\text { Broad money defined as the sum of } \\
\text { narrow money plus quasi money }\end{array}$ & + \\
\hline
\end{tabular}

Source: author's processing.

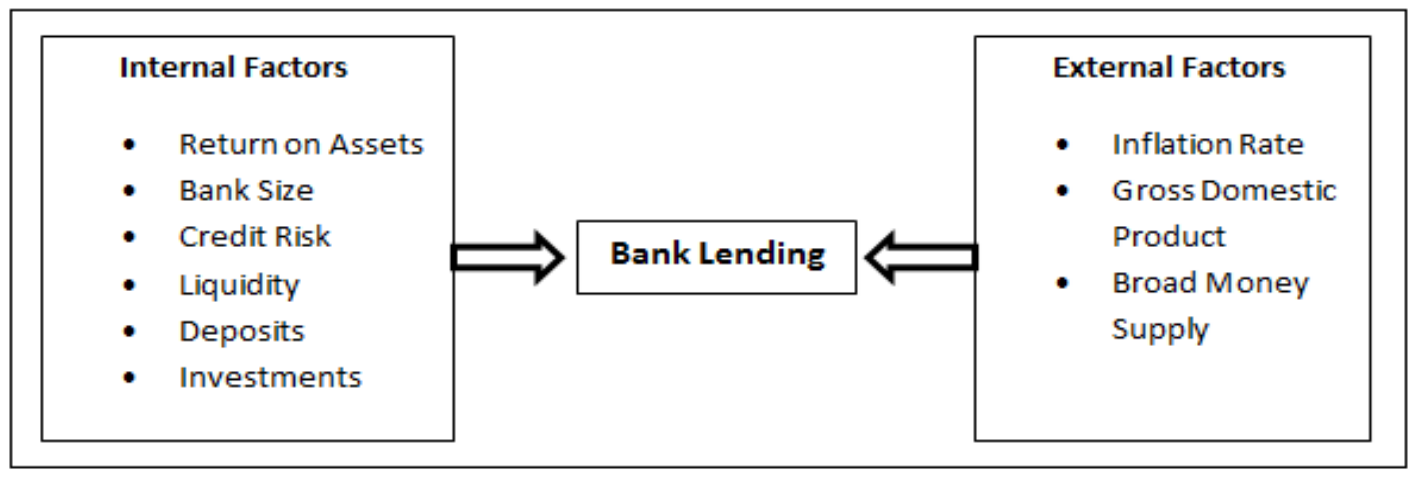

Fig. 2. Conceptual framework source: author's design

3.3. Model specifications. In the step of examining the hypotheses the study relied on the use of Ordinary Least Square model. The study has reached the equation of regression that represents the relationship between the variables studied as follows:

$$
\begin{aligned}
& L N D_{i t}=\alpha_{0}+\beta_{1} R O A_{i t}+\beta_{2} B Z_{i t}+\beta_{3} C R_{i t}+\beta_{4} L R_{i t}+ \\
& +\beta_{5} D E P_{i t}+\beta_{6} I P_{i t}+\beta_{7} I N F_{i t}+\beta_{8} G D P_{i t}+\beta_{9} M 2_{i t}+\mu,(1)
\end{aligned}
$$

where:

$L N D_{i t}$ : credit facilities of bank $i$ at time $t$;

$R O A_{i t}:$ return on assets of bank $i$ at time $t$;

$B Z_{i t}$ : size of bank $i$ at time $t$;

$C R_{i t}$ : credit risk of bank i at time $t$;

$L R_{i t}$ : liquidity ratio of bank $i$ at time $t$;

$D E P_{i t}$ : deposits of bank $i$ at time $t$;

$I P_{i t}$ : investment portfolio of bank $i$ at time $t$;

$I N F_{i t}$ : inflation rate;

$G D P$ : gross domestic product;

$M_{2}$ : broad money supply;

$\beta_{1}-\beta_{9}$ : are coefficients of the independent variables;

$\mu$ : error term or residual in the model;

$\alpha$ : intercept of the regression.

\section{Results and discussion}

\subsection{Analysis of descriptive statistics.}

Table 4. The descriptive statistics for the variables

\begin{tabular}{|l|c|c|c|c|c|}
\hline Variable & Observations & Mean & $\begin{array}{c}\text { Standard } \\
\text { deviation }\end{array}$ & Minimum & Maximum \\
\hline ROA & 91 & 0.015166 & 0.006935 & -0.001700 & 0.049700 \\
\hline BZ & 91 & 9.231 & 0.428 & 8.753 & 10.326 \\
\hline CR & 91 & 0.0988 & 0.0634 & 0.0024 & 0.328 \\
\hline LR & 91 & 0.3012 & 0.0734 & 0.1462 & 0.4753 \\
\hline DEP & 91 & 0.6484 & 0.0889 & 0.4187 & 0.8764 \\
\hline IP & 91 & 0.3901 & 0.0629 & 0.2428 & 0.5202 \\
\hline INF & 91 & 0.0528 & 0.0442 & -0.007 & 0.140 \\
\hline GDP & 91 & 0.047 & 0.024 & 0.023 & 0.082 \\
\hline M2 & 91 & 27350 & 17093.75 & 20156 & 32876 \\
\hline
\end{tabular}

Table 4 displays the descriptive statistics of the model, where LND is a dependent variable. In the directly above table, ROA, BZ, CR, LR, DEP, IP, INF, GDP and M2 are independent variables. The sample size covers 91 observations for the period 2010-2016 of thirteen banks. The minimum and maximum values of ROA as an example are 
-0.001700 and 0.049700 correspondingly, whereas the mean value is 0.015166 and standard deviation is 0.006935 and the rest of explanatory variables are as shown above in the table.

\subsection{Econometrical tests.}

Table 5. Variance inflation factor, VIF

\begin{tabular}{|l|c|c|}
\hline \multicolumn{1}{|c|}{ Variable } & VIF & $1 / \mathrm{VIF}$ \\
\hline ROA & 1.64 & 0.496247 \\
\hline BZ & 2.23 & 0.169714 \\
\hline CR & 3.72 & 0.150717 \\
\hline LR & 2.79 & 0.438361 \\
\hline DEP & 2.47 & 0.582349 \\
\hline IP & 4.84 & 0.164582 \\
\hline INF & 1.67 & 0.524539 \\
\hline GDP & 1.46 & 0.498474 \\
\hline M2 & 2.19 & 0.485738 \\
\hline Mean VIF & \multicolumn{2}{|c|}{2.55} \\
\hline
\end{tabular}

This study on the examination of the existence of multicollinearity problem was based on the Variance Inflation Factor (VIF), which is shown in Table 5, where many of the previous studies adopted the same method, which was also proposed by many specialists; for example, Gujarati (2005) suggests that this problem is absent in the case of VIF is more than 5. Moreover, Malede (2014) demonstrates that, no multicollinearity problem is present if VIF is less than 10 and $1 / \mathrm{VIF}$ is greater than 0.1 . To investigate the presence of heteroskedasticity, as suggested in previous literature, for example, the study of Malede (2014) and Moussa and Chedia (2016), it was appropriate to use the Breusch-Pagan/CookWeisberg test, where: Null hypothesis, $H_{\mathrm{o}}$ : Constant variance, Prob $>c h i^{2}=0.286$. Based on the fact that the result was not significant (Prob $>c h i^{2}$ $=0.286$ ), this means to accept null hypothesis, which states there is homoscedasticity (constant variance) and absence of heteroskedasticity.

Moreover, to test if there are factors not included in the utilized model, Ramsey Test is normally employed where null hypothesis is $H_{\mathrm{o}}$ : model has no omitted variables. As the result was significant (Prob $>\mathrm{F}=0.0000)$, it means that there are some other factors can be included to enhance the model specification.

To test for random versus fixed effect in the model by using Hausman test, null hypothesis states, $H_{\mathrm{o}}$ : difference in coefficients not systematic, the result was statistically not significant (Prob $>c h i^{2}$ $=0.678)$. Consequently, null hypothesis is accepted which states the association between the dependent variable and the explanatory variable is not fixed but random. Furthermore, Breusch and Pagan Lagrangian Multiplier Test for Random
Effect was employed where $P r o b>c h i^{2}=0.4126$ show insignificant result. At this point, examination indicated random effects are not suitable and there is no sign of significant differences through banks. As a result, simple OLS regression was selected. Breusch-Godfrey LM test for autocorrelation also was used null hypothesis: $H_{0}$ : no serial correlation. As Breusch Godfrey result was not significant (Prob $\left.>c h i^{2}=0.5672\right)$, null hypothesis was accepted, which states no serial correlation in the model.

\subsection{Findings of estimations and interpretations.}

Table 6. Results of regression

\begin{tabular}{|c|c|c|c|c|c|}
\hline LND & Coefficient & Std. error & Z & $P>|z|$ & {$[95 \% \mathrm{Cl}]$} \\
\hline ROA & 2.0362 & 5.3425 & 0.3811 & 0.0073 & 3.780 .05 \\
\hline BZ & 0.0673 & 0.1100 & 2.6786 & 0.0090 & 0.420 .18 \\
\hline CR & -0.0231 & 0.0412 & 7.9241 & 0.0950 & $0.13 \quad 1.76$ \\
\hline LR & -0.6591 & 0.2123 & -3.5902 & 0.0420 & $-0.03 \quad 0.05$ \\
\hline DEP & -0.0167 & 0.0012 & -1.5703 & 0.2640 & -0.230 .07 \\
\hline IP & 0.0004 & 0.0035 & 0.1200 & 0.9030 & 0.630 .72 \\
\hline INF & 0.1826 & 1.7242 & 1.0810 & 0.0280 & 1.286 .87 \\
\hline GDP & 2.7333 & 0.0098 & 2.7458 & 0.0075 & -2.040 .90 \\
\hline M2 & 0.5376 & 2.1524 & 7.9102 & 0.0480 & -2.04 0.90 \\
\hline Constant & 0.0365 & 0.0025 & 1.1350 & 0.2573 & $-0.04 \quad 1.05$ \\
\hline $\mathrm{R}^{2}$ & \multicolumn{5}{|c|}{0.738} \\
\hline Adj $R^{2}$ & \multicolumn{5}{|c|}{0.689} \\
\hline$D$-W stat & \multicolumn{5}{|c|}{1.796} \\
\hline $\begin{array}{l}\text { F-statistic } \\
\text { Prob }\end{array}$ & \multicolumn{5}{|c|}{$\begin{array}{c}10.8782 \\
0.0000\end{array}$} \\
\hline
\end{tabular}

As shown in the regression results above in Table 6 , the coefficient of determination $\left(R^{2}\right)=0.738$ represents a statistical measure of how close the data are to the fitted regression. It largely reflects that independent variables have almost managed to explain three-quarters of change in the behavior of the dependent variable, while other factors outside the model and the error term may need to be considered to arrive at a complete interpretation of the behavior of the dependent variable under study. Overall, this relatively high value $\left(\left(\mathrm{R}^{2}\right)=\right.$ 0.738 ) clearly indicates that the model adopted is reliable in the study of bank lending and factors affecting it. Moreover, the study discovered that among the internal factors, the credit risk and liquidity ratio has a significant negative impact on bank loans while there is significant positive association between commercial bank lending and its ROA and size. Among the external factors, inflation rate, money supply and growth in gross domestic product has a significant impact on bank lending. The consequences demonstrate that broad money, inflation rate and GDP growth tend to increase credits and allowaances. On the other hand, there is no significant proof of the association between investments, volume of deposits and bank lending for the review period. The study 
proposes that commercial bank has to give more weight to credit risk and liquidity ratio, as it weakens lending, which may touch the whole economy.

Finally, a review of Durbin Watson's statistics shows clearly that the dependent variable does not face the complexities of serial correlation. As the F-statistics has confirmed, the model used was appropriate and reliable in the study of relationships. It is evident from the statistical analysis that the liquidity ratio is negatively correlated with commercial bank lending, which is in line with Moussa and Chedia (2016), and departs from the result adopted by the Maledes (2014) study. In addition, the study also found that commercial bank lending is negatively affected by credit risk and it can be seen that this result is statistically significant. The empirical findings also suggest that there is a statistically positive correlation between commercial bank lending and its size, and this result is consistent with what was reached in the following subsequent studies: Dietrich and Wanzenried (2009), and Andreas and Gabrielle (2009).

The study also showed that the gross domestic product (GDP) has a statistically positive relationship with commercial bank lending during the period of study. This is in line with conclusion of Malede (2014) and Ibrahim Mansor (2006) findings, for example. As it is clear in the results, it is obvious that the investment is linked statistically insignificant with lending to commercial banks. This explains that when the bank invests its resources in various financial instruments of interest to the bank, its lending capacity also increases. However, in this study, this result can not be relied on because it was statistically unreported, which means that in Jordan investment does not affect commercial bank lending. The reason may be explained by the lack of established financial markets to trade with different and diverse instruments. Also, as the regression coefficient reveals, the volume of deposits is another variable that has been found to be associated with a statistically significant negative correlation with commercial bank lending. This result is in contrast to the results of the studies by Malede (2014), McCarthy et al. (2010), for example, where both studies showed a positive correlation between volume of deposits and lending behavior. As a result, this may be because most of the deposits received by the bank are often demand deposits or the volume of withdrawals is relatively high. Consequently, banks may have to maintain a large amount of customer deposits as a reserve to meet withdrawals rather than to lend.

\section{Conclusion, recommendations and suggestions for further research}

The main objective when establishing a bank is to contribute to economic development by providing loans to individuals or companies. This service is the main means by which the bank can obtain returns for profit and to continue its operations in the future. Accordingly, and in recognition of the importance of lending to banks to enable them to continue to support the economy with the necessary needs of funds, it is necessary and important to know the factors governing the bank lending. In the context of Jordan, the study examined a sample of 13 banks during the period 2010-2016. It was discovered that the determinants of commercial bank lending are: credit risk, liquidity ratio, ROA, size, inflation rate, money supply and growth in gross domestic product. Moreover, there is no significant sign of the relation between investments, volume of deposits and bank lending for the study period.

Furthermore, based on the results regarding the positive impact of the size of the bank on bank lending and also the impact of credit risk, it is possible to recommend that the legislation work to encourage the assets of the bank, which means that this will increase the ability to provide facilities and loans with relatively low credit risk correspond with the good and organized environment of banks.

Confirming what was suggested by the study of Malede (2014) and as this study focused only on the determinants of bank lending on the supply side of banks, therefore, for future research proposals, it is desirable to increase the scope of the research to include the supply side of banks and the demand for loans by individuals and institutions and to try to reach a more precise detail regarding the determinants of lending behavior by the effect of supply and demand interaction together or making comparisons between determinants of lending in developed and developing countries. It is also proposed to compare the determinants of lending in commercial banks and the determinants of facilities offered by Islamic banks in many countries. The study concentrated only on the determinants of banks' lending on supply side. So and for future research proposals, if someone investigates variables that may affect individuals demand for loan by highlighting both supply and demand side determinants of loan and by incorporating excluded banks - the finding may be fairly fruitfull.

Acknowledgements: the author is grateful to the Middle East University, Amman, Jordan for the financial support granted to cover the publication fee of this research article. 


\section{References}

1. Acharya, D., Amanulla, S., and Joy, S. (2009). Financial Development and Economic Growth in Indian States: An Examination. International Research Journal of Finance and Economics, 24, 117-130.

2. Akinlo, A. E., and Oni, I. O. (2015). Determinants of bank credit growth in Nigeria 1980-2010. European Journal of sustainable development, 4(1), 23.

3. Al-abedallat, A. Z. (2017). The Role of the Jordanian Banking Sector in Economic Development. International Business Research, 10(4), 139.

4. Al-Kilani, Q. A., and Kaddumi, T. A. (2015). Cyclicality of Lending Behavior by Banking Sector for the Period (2000-2013): Evidence from Jordan. International Journal of Economics and Finance, 7(4), 57.

5. Amidu, M. (2014). What Influences Banks Lending in Sub-Saharan Africa? Journal of Emerging Market Finance, 13(1), 1-42.

6. Andreas, D., and Gabrielle W. (2009). What determines the Profitability of Commercial Banks? New Evidence from Switzerland. Institute of Financial Services, Lucerne University of Applied Sciences, Switzerland.

7. Awdeh, A. (2016). The Determinants of Credit Growth in Lebanon. International Business Research, $10(2), 9$.

8. Ayieyo, J. O. (2016). Determinants of Lending Behavior in Selected Commercial Banks in Kenya. International Journal Of Economics, Commerce And Management, 2(9).

9. Banga, S. (2013). Socio-Economic Significance of Commercial Banks in India: With Special Emphasis on Public Sector Banks. International Journal of Advanced Research in Management and Social Sciences, 2(1), 1-22.

10. Chernykh. L., Theodossiou., A. (2011). Determinants of bank long term lending behavior: Evidence from Russia. Multinational Finance Journal, 15(1), 193-2.

11. Dietrich, A., and Wanzenried, G. (2009, February). What determines the profitability of commercial banks? New evidence from Switzerland. In 12th Conference of the Swiss Society for Financial Market Researches. Geneva. Discussion Paper.

12. Gujarati, D. N. (2005). Basic econometrics, 4, 304-331.

13. Hanh, P. T. H. (2014). Determinants of bank lending. LEMNA, Institue of Economics and Management University of Nante. Retrieved from https://hal.inria.fr

14. Ibrahim, M. H. (2006). Stock prices and bank loan dynamics in a developing country: The case of Malaysia. Journal of Applied Economics, 9(1), 71.

15. Ladime, J., Sarpong-Kumankomah, E., and Osei, K. A. (2013). Determinants of bank lending behavior in Ghana. Journal of Economics and Sustainable Development, 4(17), 42-47.

16. Laffont, J. J., and Garcia, R. (1977). Disequilibrium econometrics for business loans. Econometrica. Journal of the Econometric Society, 1187-1204.

17. Malede, M. (2014). Determinants of Commercial Banks Lending: Evidence from Ethiopian Commercial Banks. European Journal of Business and Management, 6(20), 109-117.

18. McCarthy, M., Schneider, D., and Tibb, S. (2010). Investments and loans in US banks. Journal of Bank Accounting and Finance, 19-24.

19. Melitz, J., and Pardue, M. (1973). The demand and supply of commercial bank loans. Journal of Money, Credit and Banking, 5(2), 669-692.

20. Moreno, C. A. Q., Moreno, D. F., and Estrada, D. (2012). Credit determinants and their impact on firm's growth in Colombia. Temas, 67, 1-24.

21. Moussa, M. A. B., and Chedia, H. (2016). Determinants of Bank Lending: Case of Tunisia. International Journal of Finance and Accounting, 5(1), 27-36.

22. Rabab'ah, M. (2015). Factors Affecting the Bank Credit: An Empirical Study on the Jordanian Commercial Banks. International Journal of Economics and Finance, 7(5), 166-178.

23. Tomak, S. (2013). Determinants of commercial bank lending behavior: Evidence from Turkey. Asian Journal of Empirical Research, 3(8), 933-943. 